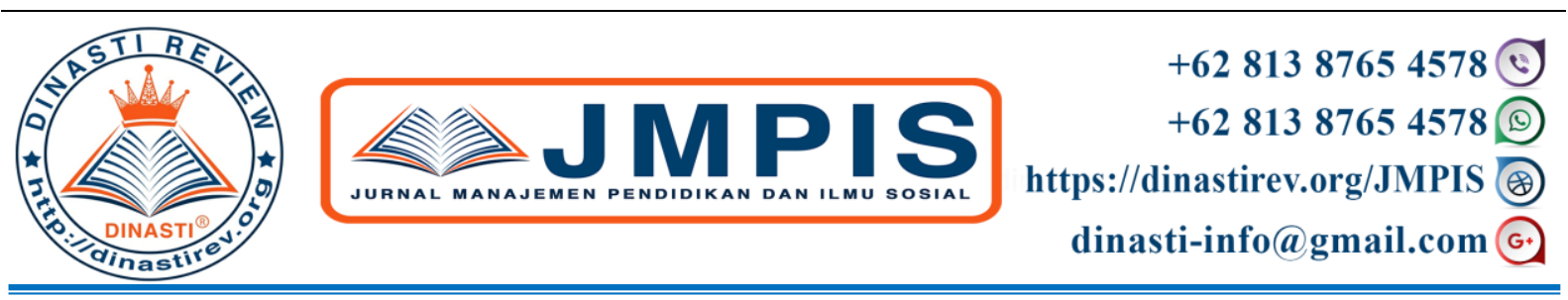

\title{
PENGARUH KOMPETENSI PROFESIONAL GURU, PEMANFAATAN SUMBER BELAJAR DAN MOTIVASI BELAJAR TERHADAP HASIL BELAJAR SISWA PADA MATA PELAJARAN EKONOMI DI SMA NEGERI 1 BAYUNG LENCIR
}

\section{Titin Herawati ${ }^{1}$, Muazza ${ }^{2}$}

1) Alumni Program Magister Pendidikan Ekonomi Universitas Jambi, Jambi, Indonesia

${ }^{2)}$ Dosen Program Magister Pendidikan Ekonomi Universitas Jambi, Jambi, Indonesia

\begin{tabular}{|c|c|}
\hline $\begin{array}{c}\text { ARTICLE INFORMATION } \\
\text { Received: } 20 \text { Juni } 2020 \\
\text { Revised: 5 Juli } 2020 \\
\text { Issued: 10 Juli } 2020 \\
\text { Corresponding author: first author } \\
\text { E-mail: } \\
\text { titinherawati456@ gmail.com }\end{array}$ & $\begin{array}{l}\text { Abstrak: Tujuan penelitian untuk menganalisis: 1) pengaruh } \\
\text { langsung dan tidak langsung kompetensi professional guru } \\
\text { terhadap motivasi belajar; 2) pengaruh langsung dan tidak } \\
\text { langsung pemanfaatan sumber belajar terhadap motivasi belajar; } \\
\text { 3) pengaruh kompetensi professional guru dan sumber belajar } \\
\text { secara bersama-sama terhadap motivasi belajar; 4) pengaruh } \\
\text { langsung dan tidak langsung kompetensi professional guru } \\
\text { terhadap hasil belajar; 5) pengaruh langsung dan tidak langsung } \\
\text { pemanfaatan sumber belajar terhadap hasil belajar; 6) pengaruh } \\
\text { langsung dan tidak langsung motivasi belajar terhadap hasil } \\
\text { belajar; dan 7) pengaruh kompetensi professional guru dan } \\
\text { sumber belajar secara bersama-sama melalui motivasi belajar } \\
\text { terhadap hasil belajar. Teknis analisis yang digunakan dalam } \\
\text { penelitian ini adalah analisis jalur (path analisys) yang bantu } \\
\text { menggunakan alat SPSS } 21.0 \text {. Hasil penelitian ini menyimpulkan: } \\
\text { 1) Kompetensi professional guru berpengaruh positif dan } \\
\text { signifikan terhadap motivasi belajar siswa; 2) Pemanfaatan } \\
\text { sumber belajar berpengaruh positif dan signifikan terhadap } \\
\text { motivasi belajar siswa; 3) Kompetensi professional guru dan } \\
\text { pemanfaatan sumber belajar secara simultan berpengaruh positif } \\
\text { dan signifikan terhadap motivasi belajar siswa; 4) Kompetensi } \\
\text { professional guru berpengaruh positif dan signifikan terhadap } \\
\text { hasil belajar siswa; 5) Pemanfaatan sumber belajar berpengaruh } \\
\text { positif dan signifikan terhadap hasil belajar siswa; 6) Motivasi } \\
\text { belajar berpengaruh positif dan signifikan terhadap hasil belajar } \\
\text { siswa; 7) Kompetensi profesional guru, pemanfaatan sumber } \\
\text { belajar dan motivasi belajar secara simultan berpengaruh positif } \\
\text { dan signifikan terhadap hasil belajar siswa; dan } 8 \text { ) Kompetensi } \\
\text { professional guru dan pemanfaatan sumber belajar secara } \\
\text { bersama-sama melalui motivasi belajar dapat berpengaruh } \\
\text { langsung dan tidak langsung terhadap terhadap hasil belajar siswa } \\
\text { pada SMA Negeri } 1 \text { Bayung Lencir. } \\
\text { Kata Kunci: Kompetensi Profesional Guru, Pemanfaatan Sumber } \\
\text { Belajar, Motivasi Belajar, dan Hasil Belajar. }\end{array}$ \\
\hline
\end{tabular}

\section{PENDAHULUAN}

Sekolah sebagai lembaga pendidikan formal memegang peran signifikan dalam proses pengajaran. Pendidikan dapat mengubah pandangan hidup, budaya dan perilaku manusia. Pendidikan juga berfungsi mengantar manusia menguak tabir kehidupan sekaligus 
menempatkan dirinya sebagai pelaku dalam setiap perubahan. Pendidikan menurut Meier (2009:41) bertujuan menyiapkan manusia untuk menghadapi berbagai perubahan yang membutuhkan kekuatan pikiran, kesadaran dan kreatifitas.

Untuk mewujudkan hal tersebut tentu saja harus didukung dengan guru yang memiliki kompetensi yang baik dalam upaya memberikan kualitas belajar yang baik. Tak terkecuali pula dengan Sekolah Menengah Atas Negeri (SMAN) 1 Bayung Lencir. Sudah menjadi suatu kewajiban yang mutlak bagi guru untuk memberikan kualitas belajar yang baik untuk mewujudkan siswa-siswi yang berprestasi dalam rangka menghadapi persaingan yang semakin ketat saat ini. Selain itu pula merupakan suatu kebanggaan tersendiri bagi guru jika siswa-siswi didiknya dapat mencapai hasil belajar yang memuaskan.

Salah satu upaya untuk mencapai tujuan pendidikan tersebut adalah dengan meningkatkan mutu pendidikan. Mutu pendidikan yang baik sangat tergantug pada proses belajar yang dilakukan siswa sebagai peserta didik. Mutu pendidikan yang baik antara lain dilihat dari hasil belajar yang dicapai oleh siswa. Hasil belajar dikatakan tercapai apabila siswa mengalami perkembangan dan peningkatan perilaku yang diharapkan dalam perumusan tujuan pembelajaran yang dibuktikan dan ditunjukan melalui nilai dari hasil evaluasi yang dilakukan oleh guru terhadap siswa melalui ulangan-ulangan atau ujian yang ditempuhnya. Hasil belajar yang baik merupakan hal yang paling didambakan oleh semua siswa. Hasil belajar dapat dijadikan indikator seorang siswa dalam kegiatan belajar.

Hasil belajar merupakan hasil yang telah dicapai oleh siswa setelah mendapat pengajaran dalam kurun waktu tertentu. Hasil belajar dapat diartikan pula sebagai sebuah cerminan dari usaha belajar. Semakin baik usaha belajar siswa, idealnya semakin baik pula hasil belajar yang akan mereka raih. Karenanya, hasil belajar dapat menjadi salah satu acuan dalam menilai keberhasilan pembelajaran yang dialami siswa.

Secara teori banyak faktor yang dapat mempengaruhi hasil belajar. Menurut Slameto (2015:54) faktor yang mempengaruhi hasil belajar meliputi dua faktor yaitu "faktor intern dan ekstern. Faktor intern adalah faktor yang ada dalam diri individu yang sedang belajar. Faktor intern dikelompokan menjadi faktor jasmaniah, faktor psikologis dan faktor kelelahan.Faktor ekstern adalah faktor yang ada di luar diri individu. Faktor ekstern meliputi: faktor keluarga, faktor sekolah dan faktor masyarakat.

Dalam dunia pendidikan faktor eksternal seperti guru adalah faktor yang sangat vital dalam memberikan hasil belajar siswa dapat tercapai. Hal ini dikemukakan oleh Sagala (2011:39) yang menyatakan bahwa guru adalah salah satu faktor penting dalam penyelenggaran pendidikan di Sekolah. Karena guru mempunyai tanggung jawab untuk mengamati perkembangan dalam belajarnya. Guru harus mampu menciptakan iklim belajar menarik, aman, nyaman, dan kondusif di kelas. Keberadaannya di tengah-tengah dapat mencairkan suasana kekakuan dan kejenuhan belajar yang terasa berat diterima oleh siswa. Oleh karenanya sudah semestinya seorang guru haruslah professional dalam menjalani profesinya sebagai tenaga pendidik.

Selain kompetensi profesional guru dalam upaya meningkatkan hasil belajar peserta didik, hal penting lainnya yang perlu diperhatikan oleh seorang guru untuk meningkatkan hasil belajar peserta didiknya yaitu dengan pemanfaatkan sumber belajar. Hal ini penting, agar apa yang dipelajari sesuai dengan kondisi dan perkembangan masyarakat, sehingga tidak terjadi kesenjangan dalam pola pikir peserta didik (Mulyasa, 2013:156). Sumber belajar merupakan suatu unsur yang memiliki peranan penting dalam menentukan proses pembelajaran, karena didalamnya akan menjadi efektif dan efisien untuk mencapai ketuntasan belajar dengan melibatkan komponen proses belajar secara terencana. 
Selain faktor eksternal, adapun faktor lain yang tidak kalah pentingnya dalam mempegaruhi hasil belajar adalah faktor internal yang berhubungan dengan motivasi belajar siswa. Motivasi belajar merupakan salah satu aspek psikis yang membantu dan mendorong seseorang untuk mencapai tujuannya. Maka motivasi harus ada dalam diri seseorang, sebab motivasi merupakan modal dasar untuk mencapai tujuan. Dengan demikian, motivasi harus menjadi pangkal permulaan dari pada semua aktivitas.

Berangkat dari fenomena yang telah dikemukakan, maka menimbulkan ketertarikan untuk mengangkat tema ini menjadi suatu kajian empirik dengan judul "Pengaruh Kompetensi Profesional Guru dan Pemanfaatan Sumber Belajar Terhadap Hasil Belajar Siswa yang Dimediasi oleh Motivasi Belajar pada Mata Pelajaran Ekonomi di SMA Negeri 1 Bayung Lencir".

Sesuai dengan permasalahan yang diajukan dalam penelitian, maka tujuan dari peneltian ini yaitu: 1) Untuk menganalisis pengaruh kompetensi professional guru terhadap motivasi belajar; 2) Untuk menganalisis pengaruh pemanfaatan sumber belajar terhadap motivasi belajar; 3) Untuk menganalisis pengaruh kompetensi professional guru dan sumber belajar secara bersama-sama terhadap motivasi belajar; 4) Untuk menganalisis pengaruh kompetensi professional guru terhadap hasil belajar; 5) Untuk menganalisis pengaruh pemanfaatan sumber belajar terhadap hasil belajar; 6) Untuk menganalisis pengaruh motivasi belajar terhadap hasil belajar; dan 7) Untuk menganalisis pengaruh kompetensi professional guru dan sumber belajar secara bersama-sama melalui motivasi belajar terhadap hasil belajar.

\section{KAJIAN PUSTAKA}

\section{Hasil Belajar}

Sudjana (2016:22) menyatakan hasil belajar adalah kemampuan kemampuan yang dimiliki siswa setelah ia memiliki pengalaman belajarnya. Howard Kingsley membagi tiga macam hasil belajar, yakni a) keterampilan dan kebiasaan, b) pengetahuan dan pengertian, c) sikap dan cita-cita. Masing-masing jenis hasil belajar dapat diisi dengan bahan yang telah ditetapkan dalam kurikulum. Sedangkan Gagne membagi lima kategori hasil belajar, yakni a) informasi verbal, b) keterampilan intelektual, c) strategi kognitif, d) sikap, dan e) keterampilan motoris. Dalam system pendidikan nasional rumusan tujuan pendidikan, baik tujuan kurikuler maupun tujuan instruksional, menggunakan klasifikasi hasil belajar dari Benyamin Bloom yang secara garis besar membaginya menjadi tiga ranah, yakni ranah kognitif, ranah afektif, dan ranah psikomotoris (Sudjana, 2016:22).

Hasil belajar menurut Supardi (2015:2) tahap pencapaian actual yang ditampilkan dalam bentuk perilaku yang meliputi aspek kognitif, afektif, maupun psikomotor dan dapat dilihat dalam bentuk kebiasaan, sikap, dan penghargaan. Sedangkan menurut Dimyati dan Mudjiono (2009:3) hasil belajar adalah hasil dari suatu interaksi tindakan belajar dan tindakan mengajar. Hasil belajar merupakan salah satu indikator dari proses belajar. Hasil belajar adalah perubahan perilaku yang diperoleh siswa setelah mengalami aktivitas belajar (Anni, 2014:4).

Hasil belajar adalah perubahan tingkah laku peserta didik setelah mengikuti poses belajar mengajar yang dapat dilihat melalui aspek 1) Ranah Rasa (Afektif); 2) Ranah Cipta (Kognitif); dan 3) Ranah Karsa (Psikomotor) (Surya, Barlow dan Petty dalam Syah, 2017:148). Adapun indikator yang digunakan untuk mengukur hasil belajar siswa adalah nilai rapor siswa setiap semesternya.

\section{Kompetensi Profesional Guru}

Kompetensi profesional adalah kemampuan penguasaan materi pembelajaran secara luas dan mendalam yang memungkinkan membimbing peserta didik memenuhi standar kompetensi yang ditetapkan dalam Standar Nasional Pendidikan (Standar Nasional 
Pendidikan Pasal 28 ayat (3) butir c). Kompetensi Profesional adalah kemampuan penguasaan materi pelajaran secara luas dan mendalam, serta metode dan teknik mengajar yang sesuai yang dipahami oleh murid, mudah ditangkap, tidak menimbulkan kesulitan dan keraguan (Alma dalam Arfah, M dan Muhidin, A., 2018:44).

Kompetensi profesional guru menurut Syah, M (2017:229) diartikan sebagai kemampuan dan kewenangan guru dalam menjalankan profesi keguruannya. Artinya guru yang piawai dalam melaksanakan profesinya dapat disebut sebagai guru yang kompeten dan professional. Menurut Jamil dalam Shadrina, D.N., Asriati, N., dan Utomo, B.B (2015:2), "Kompetensi profesional merupakan kemampuan guru dalam menguasai pengetahuan bidang ilmu pengetahuan, teknologi dan/atau seni dan budaya yang diampunya.

Kompetensi adalah seperangkat pengetahuan, keterampilan, dan perilaku yang harus dimiliki, dihayati, dan dikuasai oleh guru dalam menjalankan tugas utamanya sebagai pendidik, pengajar, pembimbing, pengarah, pelatih, penilai peserta didik pada jenjang pendidikan dasar dan menengah. Kompetensi professional guru dapat diukur melalui 5 indikator inti yaitu 1) Menguasai Materi Standar; 2) Mengelola Kelas; 3) Menggunakan Media dan Sumber Pembelajaran; 4) Menampilkan Keteladanan dan Kepemimpinan dalam Pembelajaran; dan 5) Mengelola Program Pembelajaran (Mulyasa, 2013:136).

\section{Pemanfaatan Sumber Belajar}

Association of Educational Communication Technology (AECT) (Warsita, 2010:211) mendefinisikan bahwa sumber belajar sebagai semua sumber baik berupa data, orang atau benda yang dapat digunakan untuk memberikan fasilitas (kemudahan) belajar bagi siswa. Begitupun dengan Mulyasa (2013:13) mengatakan bahwa sumber belajar dapat dirumuskan sebagai segala sesuatu yang dapat memberikan keudahan kepada siswa dalam memperoleh sejumlah informasi, pengetahuan, pengalaman dan keterampilan dalam proses belajar mengajar.

Menurut Warsita (2011:209) sumber belajar adalah semua komponen sistem instruksional baik yang secara khusus dirancang maupun yang menurut sifatnya dapat dipakai atau dimanfaatkan dalam kegiatan pembelajaran. Selain itu Sudjana dan Rivai (2009:76) mengatakan bahwa sumber belajar adalah suatu daya yang bisa dimanfaatkan guna kepentingan proses belajar mengajar baik secara langsung mupun tidak langsung, sebagian atau keseluruhan.

Selain itu Sadiman (2012:79) juga mengemukakan bahwa sumber belajar adalah segala macam yang ada di luar diri seseorang (peserta didik) dan yang memungkinkan/memudahkan terjadinya proses belajar. Kemudian Sudjana (2016:77) mengatakan bahwa sumber belajar merupakan suatu sistem atau perangkat materi yang sengaja disiapkan atau diciptakan dengan maksud memungkinkan atau memberi kesempatan siswa untuk belajar.

Sumber belajar merupakan segala sesuatu baik yang ada diluar diri peserta didik baik berupa perangkat materi yang sengaja diciptakan dengan maksud untuk memberikan kesempatan dan kemudahan kepada peserta didik dalam memperoleh sejumlah informasi, pengetahuan, pengalaman, dan keterampilan, dalam proses belajar mengajar. Yang tercermin melalui indikator yaitu: 1) Manusia; 2) Bahan Pengajaran; 3) Lingkungan; 4) Alat dan Perlengkapan Belajar; 5) Aktivitas (Teknik); dan 6) Pesan (Sudjana, 2016:79-80).

\section{Motivasi Belajar}

Motivasi adalah proses medorong dan mempertahankan tujuan dengan mengarahkan perilaku (Schunk, D.H., 2012:475). Hal ini merupakan sebuah definisi kognitif karena mendalilkan bahwa siswa membuat tujuan dan menggunakan proses kognitif (misalnya, merencanakan, mengawasi) dan perilaku (misalnya, keuletan, usaha) untuk mencapai tujuan mereka. Lebih lanjut Schunk, D.H., Pintrich, P.P., \& Meece, J.L (2012:6) menjelaskan bahwa 
motivasi merupakan suatu proses diinisiasikannya dan dipertahankannya aktivitas yang diarahkan pada pencapaian tujuan.

Luthan (2006:270) mengemukakan bahwa motivasi adalah proses yang dimulai dengan defisiensi fisiologis atau psikologis yang menggerakan perilaku atau dorongan yang ditujukan untuk tujuan atau insentif. Dengan demikian, kunci untuk memahami proses motivasi bergantung pada pengertian dan hubungan antara kebutuhan, dorongan dan insentif.

Menurut Robbin dan Judge (2015:127) motivasi merupakan proses yang menjelaskan mengenai kekuatan, arah dan ketekunan seseorang dalam upaya untuk mencapai tujuan. Robbin dan Judge mendefinisikan motivasi sebagai proses yang menjelaskan mengenai kekuatan, arah, dan ketekunan seseorang dalam upaya untuk mencapai tujuan. Oleh karena motivasi secara umum adalah berkaitan dengan upaya menuju setiap tujuan, kita kan mempersempit fokus menjadi tujuan organisasi terhadap perilaku terkait pekerjaan.

Menurut Khairinal (2016:187) motivasi adalah berkenaan dengan suatu alasan-alasan orang mencurahkan tenaga dan pikiran untuk termotivasi melakukan suatu pekerjaan sehingga menghasilkan perilaku yang memadai antar keadaan yang tidak cocok dengan keadaan yang diinginkan untuk mempertahankan tujuan dengan mengarahkan perilaku pada yang diinginkannya.

Motivasi belajar adalah suatu dorongan yang timbul dari dalam maupun luar diri seseorang untuk meningkatkan pengetahuan dan pemahaman, keterampilam dan merubah perilakunya. Yang tercermin melalui indikator yaitu: 1) Adanya hasrat dan keinginan belajar; 2) Adanya dorongan dan kebutuhan dalam belajar; 3) Adanya harapan akan cita-cita masa depan; 4) Adanya penghargaan dalam belajar; 5) Adanya kegiatan yang menarik dalam belajar; dan Adanya lingkungan belajar yang kondusif (Uno, 2017:23).

\section{Kerangka Pemikiran}

Berdasarkan pemaparan teori dan kajian dari penelitian terdahulu di atas, maka untuk menjawab permasalahan penelitian dibentuk kerangka pemikiran seperti terlihat pada gambar berikut.

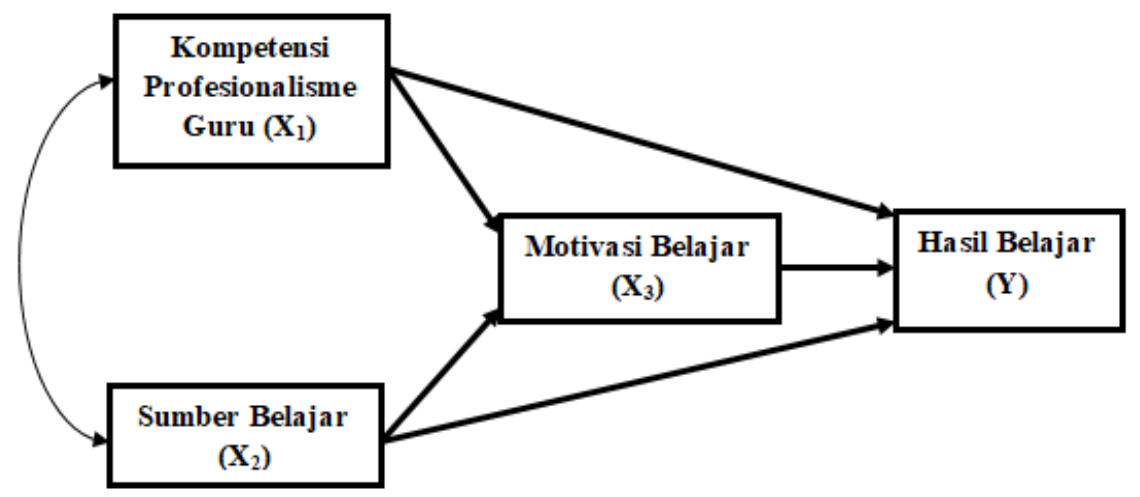

Gambar 1. Kerangka Berpikir

\section{Hipotesis}

Berdasarkan rumusan masalah dan beberapa asumsi yang telah dikemukakan terdahulu dapat dirumuskan hipotesis yang merupakan dugaan sementara. Penulis merumuskan hipotesis berkenaan dengan masalah yang diteliti sebagai berikut:

$\mathrm{H}_{1}$ : Kompetensi professional guru berpengaruh terhadap motivasi belajar.

$\mathrm{H}_{2}$ : Sumber belajar berpengaruh terhadap motivasi belajar.

$\mathrm{H}_{3}$ : Kompetensi professional guru dan sumber belajar secara bersama-sama tidak berpengaruh terhadap motivasi belajar. 
$\mathrm{H}_{4}$ : Kompetensi professional guru berpengaruh terhadap hasil belajar.

$\mathrm{H}_{5}$ : Sumber belajar berpengaruh terhadap hasil belajar.

$\mathrm{H}_{6}$ : Motivasi belajar berpengaruh terhadap hasil belajar.

$\mathrm{H}_{7}$ : Kompetensi professional guru dan sumber belajar belajar melalui motivasi belajar berpengaruh terhadap hasil belajar.

\section{METODE PENELITIAN}

Populasi dalam penelitian ini adalah siswa-siswi Sekolah Menengah Atas Negeri 1 Bayung Lencir kelas XI IPS dengan jumlah 156 siswa-siswi yang terdiri dari 4 kelas. Kelas XI dipilih dalam penelitian ini dengan pertimbangan bahwa kelas telah mengikuti pelajaran secara aktif, sedangkan kenapa bukan kelas X dan XII yang dijadikan perhatian dalam penelitian ini, karena kelas X adalah siswa/I baru, sedangkan kelas XII tidak dapat penulis amati lagi karena kelas XII telah disiapkan untuk focus untuk menghadap Ujian Akhis Nasional (UAS).

Adapun teknik sampling dalam penelitian ini melalui probability sampling. Probability sampling menurut Khairinal (2016:313) yaitu pengambilan sampel berdasarkan peluang atau kemungkinan terpilihnya setiap anggota populasi dipilih menjadi anggota sampel dapat ditentukan atau dapat diketahui atas peluang yang sama. Probability sampling yang digunakan dalam penelitian ini melalui simple random sampling (sederhana). Simple random sampling (sederhana) yaitu suatu teknik pengambilan sampel yang dilakukan dari populasi secara acak tidak memperhatikan strata yang ada dalam populasi (Khairinal, 2016:313).

Jenis penelitian yang dilakukan adalah metode penelitian kuantitatif, karena data penelitian berupa angka-angka dan analisis menggunakan statistik. Metode penelitian kuantitatif, digunakan untuk meneliti pada populasi atau sampel tertentu, teknik pengambilan sampel dilakukan secara random, pengumpulan data menggunakan instrument penelitian, analisis data bersifat kuantitatif/statistik dengan tujuan untuk menguji hipotesis yang telah ditetapkan, Sugiyono (2012:9).

Sedangkan teknis analisis dalam penelitian ini menggunakan analisis jalur (path analisys), yang dilanjutkan melakukan pengujian hipotesis melalui uji t dan uji F. Namun sebelumnya terlebih dahulu dilakukan uji instrument penelitian melalui uji validitas, reliabilitas, normalitas, homogenitas, serta linearitas. Selain menggunakan uji instrument, penulis juga melakukan uji regresi melalui uji multikolinearitas, uji heterokedastisitas, dan uji autokorelasi.

\section{HASIL DAN PEMBAHASAN}

\section{Deskripsi Variabel Penelitian}

Penelitian ini dilakukan mulai dari 21 September 2019 sampai dengan Juli 2020. Di awali dengan penyebaran instrument penelitian berupa angket yang diberikan kepada siswa melalui google form, sesuai dengan perhitungan jumlah sampel yang telah ditentukan. Semua angket yang telah di sebarkan kembali kepada penulis, dan semua instrumennya terisi dengan penuh. Pada bagian berikut ini penulis akan mendeskripsikan variabel yang diteliti satu persatu sebagai berikut.

\section{a. Deskriptif Variabel Kompetensi Profesional Guru $\left(\mathbf{X}_{1}\right)$}

Dari hasil deskriptif diketahui bahwapesepsi responden atas variable kompetensi professional guru termasuk kedalam kategori baik. Dimana yang menyatakan bahwa kompetensi professional guru pada SMA Negeri 1 Bayung Lencir sangat buruk yaitu sebesar 3,21 persen, yang menyatakan buruk sebesar 4,49 persen, kemudian yang 
menyatakan cukup baik sebesar 38,46 persen, yang menyatakan baik sebesar 41,67 persen, dan yang menyatakan bahwa sangat baik sebesar 12,18 persen.

b. Deskriptif Variabel Pemanfaatan Sumber Belajar $\left(\mathbf{X}_{2}\right)$

Dari hasil deskriptif diketahui bahwa pesepsi responden atas variable pemanfaatan sumber belajar termasuk kedalam kategori cukup baik. Dimana siswa yang memanfaatkan sumber belajar dengan sangat buruk yaitu sebesar 4,49 persen, yang mampu memanfaatkan sumber belajar dengan buruk sebesar 25 persen, kemudian yang mampu memanfaatkan sumber belajar dengan cukup baik sebesar 35,26 persen, yang mampu memanfaatkan sumber belajar dengan baik sebesar 25 persen, dan yang mampu memanfaatkan sumber belajar dengan sangat baik yaitu sebesar 10,26 persen.

c. Deskriptif Variabel Motivasi Belajar $\left(\mathrm{X}_{3}\right)$

Dari hasil deskriptif diketahui bahwasanya siswa pada SMA Negeri 1 Baying Lencir memiliki motivasi belajar yang cukup tinggi. Hal ini dibuktikan dari hasil sebaran angket yang dilakukan diperoleh hasil bahwasanya sebesar 1,28 persen kategori sangat rendah, 26,28 persen berada pada kategori rendah, kemudian 35,9 persen berada pada kategori cukup tinggi, sebesar 28,85 persen berada pada kategori tinggi, dan sebesar 7,69 persen berada pada kategori sangat tinggi. Dari hasil tersebut maka dapat di simpulkan bahwa motivasi belajar siswa pada SMA Negeri 1 Bayung Lencir, memiliki motivasi yang cukup tinggi untuk belajar.

\section{Analisis Jalur (Path Analisis)}

Untuk menjawab tujuan-tujuan dalam penelitian ini, struktur utama dalam model penelitian di pecah menjadi dua sub struktur. Dimana untuk menjawab hipotesis 1, 2, dan 3 dengan sub struktur pertama, untuk menjawab hipotesis 4, 5, dan 6, dengan menggunakan sub struktur kedua, dan untuk menjawab hipotesis 7 nilai yang digunakan adalah sub struktur pertama dan kedua. Berikut ini merupakan output SPSS dari tiga struktur yang dirangkum pada tabel berikut.

Tabel 1. Output SPSS Dua Sub Struktur.

\begin{tabular}{|c|c|c|c|c|c|c|}
\hline \multirow{2}{*}{ Model } & \multicolumn{2}{|c|}{$\begin{array}{c}\text { Unstandardized } \\
\text { Coefficients }\end{array}$} & \multirow{2}{*}{ Beta } & \multirow{2}{*}{$\mathbf{t}$} & \multirow[t]{2}{*}{$\mathbf{F}$} & \multirow{2}{*}{ Sig. } \\
\hline & B & Std.Error & & & & \\
\hline $\mathrm{X} 1-\mathrm{X} 3$ & 0,186 & 0,056 & 0,211 & 3,501 & - & 0,001 \\
\hline $\mathrm{X} 2-\mathrm{X} 3$ & 0,612 & 0,060 & 0,650 & 10,204 & - & 0,000 \\
\hline $\mathrm{X} 1, \mathrm{X} 2-\mathrm{X} 3$ & - & - & - & - & 141,013 & 0.000 \\
\hline $\mathrm{X} 1-\mathrm{Y}$ & 0,232 & 0,068 & 0,214 & 3,402 & - & 0,001 \\
\hline $\mathrm{X} 2-\mathrm{Y}$ & 0,459 & 0,091 & 0,396 & 5,035 & - & 0,000 \\
\hline X3-\& & 0,377 & 0,095 & 0,306 & 3,982 & - & 0,000 \\
\hline
\end{tabular}

Sumber: Data diolah dari output SPSS 21.0 for windwos. berikut:

Hasil output diatas di masukkan ke dalam gambar persamaan struktural sebagai 


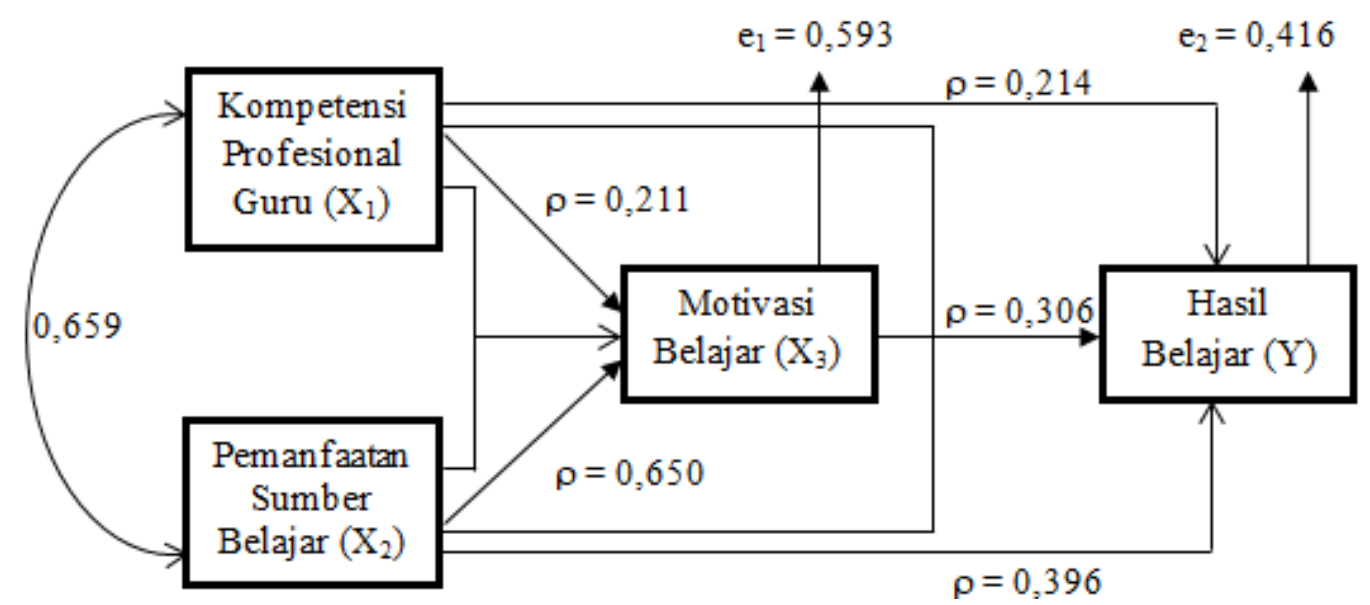

Gambar 2. Hasil Analisis Jalur

1) Pengaruh Kompetensi Professional Guru $\left(\mathbf{X}_{1}\right)$ Terhadap Motivasi $\left(\mathbf{X}_{3}\right)$

$>$ Pengaruh langsung $\mathrm{X}_{1}$ terhadap $\mathrm{X}_{3}$ sebesar 0,044521 (4,45\%)

$>$ Pengaruh tidak langsung $X_{1}$ terhadap $X_{3}$ melalui $X_{2}$ sebesar $0,09038185(9,04 \%)$

$>$ Total pengaruh langsung dan tidak langsung sebesar 13,49

2) Pengaruh Pemanfaatan Sumber Belajar $\left(\mathbf{X}_{2}\right)$ Terhadap Motivasi $\left(\mathbf{X}_{3}\right)$

$>$ Pengaruh langsung $\mathrm{X}_{2}$ terhadap $\mathrm{X}_{3}$ sebesar 0,4225 $(42,25 \%)$

$>$ Pengaruh tidak langsung $X_{2}$ terhadap $X_{3}$ melalui $X_{1}$ sebesar $0,09038185(9,04 \%)$

$>$ Total pengaruh langsung dan tidak langsung sebesar 51,29

3) Pengaruh Kompetensi Profesional Guru $\left(X_{1}\right)$ dan Pemanfaatan Sumber Belajar $\left(X_{2}\right)$ secara bersama-sama terhadap Motivasi Belajar $\left(\mathbf{X}_{3}\right)$.

$>$ Pengaruh langsung $X_{1} \& X_{2}$ terhadap $X_{3}$ sebesar $46,7 \%$.

$>$ Pengaruh tidak langsung secara bersama-sama antara $X_{1} \& X_{2}$ terhadap $X_{3}$ sebesar $18,08 \%$.

$>$ Total pengaruh langsung dan tidak langsung sebesar 64,78.

4) Pengaruh Kompetensi Profesional Guru Terhadap Hasil Belajar

$>$ Pengaruh langsung $\mathrm{X}_{1}$ terhadap $\mathrm{Y}$ sebesar 0,045796 (4,58\%)

$>$ Pengaruh tidak langsung $\mathrm{X}_{1}$ terhadap $\mathrm{X}_{3}$ melalui $\mathrm{X}_{2}$ sebesar $0,055846296(5,58 \%)$

$>$ Total pengaruh sebesar $10,16 \%$

5) Pengaruh Pemanfaatan Sumber Belajar Terhadap Hasil Belajar.

$>$ Pengaruh langsung $\mathrm{X}_{2}$ terhadap $\mathrm{Y}$ sebesar $0,156816(15,68 \%)$

$>$ Pengaruh tidak langsung $\mathrm{X}_{2}$ terhadap $\mathrm{Y}$ melalui $\mathrm{X}_{1}$ sebesar $0,055846296(5,58 \%)$

$>$ Total pengaruh sebesar $21,27 \%$

6) Pengaruh Motivasi Belajar Terhadap Hasil Belajar.

$>$ Pengaruh langsung $\mathrm{X}_{3}$ terhadap $\mathrm{Y}$ sebesar 0,093636 (9,36\%)

7) Kompetensi Profesional Guru dan Pemanfaatan Sumber Belajar Melalui Motivasi Belajar Terhadap Hasil Belajar.

a. Pengaruh Kompetensi Profesional Guru Terhadap Hasil Belajar Melalui Motivasi Belajar.

Pengaruh $\mathrm{X}_{1}$ terhadap $\mathrm{Y}$ melalui $\mathrm{X}_{3}$ sebesar 0,0138 (1,38\%)

Pengaruh tidak langsung $\mathrm{X}_{1}$ terhadap $\mathrm{Y}$ melalui $\mathrm{X}_{2}$ dan $\mathrm{X}_{3}$ sebesar $0,0280(2,80 \%)$

Total pengaruh $\mathrm{X}_{1}$ melalui $\mathrm{X}_{3}$ terhadap $\mathrm{Y}$ sebesar $4,18 \%$

b. Pengaruh Pemanfaatan Sumber Belajar Terhadap Hasil Belajar Melalui Motivasi Belajar.

Pengaruh $\mathrm{X}_{2}$ terhadap Y melalui $\mathrm{X}_{3}$ sebesar 0,0787 (7,87\%)

Pengaruh tidak langsung $\mathrm{X}_{2}$ terhadap $\mathrm{Y}$ melalui $\mathrm{X}_{1}$ dan $\mathrm{X}_{3}$ sebesar $0,0168(1,68 \%)$

Total pengaruh $\mathrm{X}_{2}$ melalui $\mathrm{Y}$ terhadap $\mathrm{X}_{3}$ sebesar $9,56 \%$ 
c. Pengaruh Kompetensi Profesional Guru dan Pemanfaatan Sumber Belajar Secara Bersama-sama Terhadap Hasil Belajar Melalui Motivasi belajar

Pengaruh $\mathrm{X}_{1}$ dan $\mathrm{X}_{2}$ terhadap Y melalui $\mathrm{X}_{3}$ sebesar 9,26\%

Pengaruh tidak langsung $\mathrm{X}_{1}$ dan $\mathrm{X}_{2}$ terhadap $\mathrm{Y}$ melalui $\mathrm{X}_{3}$ sebesar $4,48 \%$

Total pengaruh $\mathrm{X}_{1}$ dan $\mathrm{X}_{2}$ melalui $\mathrm{X}_{3}$ terhadap $\mathrm{Y}$ sebesar $13,74 \%$

\section{Pembahasan}

\section{1) Pengaruh Kompetensi Profesional Guru Terhadap Motivasi Belajar}

Pengujian hipotesis pertama dalam penelitian ini dilakukan melalui Uji-t (Uji Parsial). Dari hasil pengujian pada Tabel 1 yang dilakukan diperoleh angka nilai $\mathrm{t}$ hitung variabel $\mathrm{X}_{1}$ sebesar 3,307, dikarenakan nilai t hitung > t Tabel $(3,307>1,975)$, maka secara parsial kompetensi professional guru memiliki pengaruh terhadap motivasi belajar. Oleh karena itu maka $\mathrm{H}_{0}$ ditolak, artinya secara parsial terdapat pengaruh signifikan antara kompetensi professional guru dengan motivasi belajar siswa.

Besarnya pengaruh langsung kompetensi professional guru $\left(\mathrm{X}_{1}\right)$ terhadap motivasi belajar $\left(\mathrm{X}_{3}\right)$ bernilai positif sebesar $4,45 \%$, begitu pula untuk pengaruh tidak langsung bernilai positif sebesar $9,04 \%$ dan pengaruh total sebesar $13,49 \%$, hal ini menunjukan bahwa kompetensi professional guru secara langsung dan tidak langsung berpengaruh positif terhadap motivasi belajar siswa, dimana pengaruh tidak langsung memiliki nilai yang besar dibandingkan nilai pengaruh langsung. Hal ini menjelaskan bahwasanya jika kompetensi professional guru di dukung dengan semakin baiknya siswa dalam memanfaatkan sumber belajar yang ada, maka hal ini akan semakin meningkatkan motivasi siswa dalam belajar.

Hasil penelitian ini membuktikan dan sekaligus menjawab hipotesis bahwa terdapat pengaruh antara kompetensi professional guru terhadap motivasi belajar siswa. Hal ini menunjukkan bahwa kompetensi professional guru merupakan kekuatan yang mampu mendorong semangat belajar peserta didik. Hasil penelitian ini sejalan dengan penelitian yang dilakukan oleh Sunarti, I dan Susanti (2016) yang mengemukakan bahwa kompetensi profesional guru berpengaruh positif terhadap motivasi belajar siswa. Artinya semakin baik kompetensi seorang guru dalam memberikan pengajaran kepada didiknya, hal ini akan semakin meningkatkan motivasi belajar siswa untuk mengikuti materi yang diberikan oleh guru tersebut. Sebaliknya, semakin buruknya kompetensi seorang guru dalam mengajar, maka hal ini akan semakin rendahnya motivasi peserta didik untuk mengikuti pelajaran di sekolah.

\section{2) Pengaruh Pemanfaatan Sumber Belajar Terhadap Motivasi Belajar}

Pengujian hipotesis kedua dalam penelitian ini dilakukan melalui Uji-t (Uji Parsial). Dari hasil pengujian pada Tabel 1 yang dilakukan diperoleh angka nilai $t$ hitung variabel $\mathrm{X}_{2}$ sebesar 10,204, dikarenakan nilai t hitung > t Tabel $(10,204>1,975)$, maka secara parsial pemanfaatan sumber belajar memiliki pengaruh terhadap motivasi belajar. Oleh karena itu maka $\mathrm{H}_{0}$ ditolak, artinya secara parsial terdapat pengaruh signifikan antara pemanfaatan sumber belajar dengan motivasi belajar siswa.

Besarnya pengaruh langsung pemanfaatan sumber belajar $\left(\mathrm{X}_{2}\right)$ terhadap motivasi belajar $\left(\mathrm{X}_{3}\right)$ bernilai positif sebesar $42,25 \%$, begitu pula untuk pengaruh tidak langsung bernilai positif sebesar $9,04 \%$ dan pengaruh total sebesar $51,29 \%$, hal ini menunjukan bahwa pemanfaatan sumber belajar secara langsung dan tidak langsung berpengaruh positif terhadap motivasi belajar, dimana pengaruh langsung memiliki nilai yang besar dibandingkan nilai tidak langsung. Hal ini menjelaskan bahwasanya apabila siswa mampu memanfaatkan sumber belajar yang ada, baik yang ada disekolah maupun yang berada di luar lingkungan sekolah, maka hal ini akan mampu meningkatkan motivasi siswa dalam belajar.

Hasil penelitian ini sejalan dengan penelitian yang dilakukan oleh Wati, N.D.K., Nuraini., Bambang, GS (2016) yang mengemukakan bahwa pemanfaatan sumber belajar berpengaruh positif terhadap motivasi belajar siswa. Artinya apabila siswa mampu 
memanfaatkan sumber belajar yang ada dilingkungan sekolah maupun yang berada diluar lingkungan sekolah dengan baik, maka akan mampu meningkatkan motivasi belajar siswa. Sebaliknya, jika siswa kurang bisa memanfaatkan sumber belajar yang ada, maka hal ini akan membuat motivasi belajar siswapun semakin menurun.

\section{3) Pengaruh Kompetensi Profesional Guru dan Pemanfaatan Sumber Belajar Terhadap Motivasi Belajar.}

Dari uji Anova atau $\mathrm{F}$ test dengan menggunakan SPSS 21.0 didapat $\mathrm{F}_{\text {hitung }}$ sebesar 141,013 dengan tingkat probabilitas $p$-value sebesar 0,000 , dikarenakan nilai $F_{\text {hitung }}>\mathrm{F}_{\text {tabel }}$ $(141,013>3,05)$ sehingga dapat disimpulkan bahwa hipotesis nol $\left(\mathrm{H}_{0}\right)$ ditolak dan Hipotesa alternatif $\left(\mathrm{H}_{1}\right)$ diterima, artinya ada pengaruh signifikan antara kompetensi profesional guru dan pemanfaatan sumber belajar secara bersama-sama terhadap motivasi belajar. Jadi pada penelitian ini dapat disimpulkan bahwa 1 kompetensi profesional guru dan pemanfaatan sumber belajar secara simultan berpengaruh terhadap motivasi belajar siswa pada SMA Negeri 1 Bayung Lencir.

Selain itu pula perhitungan nilai total pengaruh langsung dan tidak langsung kompetensi professional guru dan pemanfaatan sumber belajar secara bersama-sama terhadap motivasi belajar sebesar $64,78 \%$, dimana angka tersebut menjelaskan bahwa secara langsung kompetensi professional guru dan pemanfaatan sumber belajar memberikan kontribusi terhadap motivasi motivasi belajar sebesar $64,78 \%$. Dimana Nilai total pengaruh $\mathrm{X}_{1}, \mathrm{X}_{2}$ tersebut menjelaskan nilai koefisien determinasi $\mathrm{R}^{2}$, dimana nilai $\mathrm{R}$ sebesar 0,805 menunjukan korelasi ganda (kompetensi profesional guru dan pemanfaatan sumber belajar) dengan motivasi belajar. Dengan mempertimbangkan variasi Nilai R Square sebesar 0,648 yang menunjukan besarnya peran atau kontribusi kompetensi profesional guru dan pemanfaatan sumber belajar mampu menjelaskan variabel motivasi belajar sebesar $64,8 \%$ dan sisanya 35,2\% dipengaruhi oleh variabel lain yang tidak termasuk dalam model ini.

\section{4) Pengaruh Kompetensi Profesional Guru Terhadap Hasil Belajar}

Tujuan keempat dalam penelitian ini yakni ingin mengetahui pengaruh kompetensi profesional guru terhadap hasil belajar, pengujian dilakukan melalui Uji-t (Uji Parsial). Dari hasil pengujian pada Tabel 1 yang dilakukan diperoleh angka nilai t hitung variabel $\mathrm{X}_{1}$ sebesar 3,402, dikarenakan nilai t hitung > t Tabel $(3,402>1,975)$, maka secara parsial kompetensi professional guru memiliki pengaruh terhadap hasil belajar. Oleh karena itu maka $\mathrm{H}_{0}$ ditolak, artinya secara parsial terdapat pengaruh signifikan antara kompetensi professional guru dengan hasil belajar siswa.

Besarnya pengaruh langsung kompetensi professional guru $\left(\mathrm{X}_{1}\right)$ terhadap hasil belajar (Y) bernilai positif sebesar $4,58 \%$, begitu pula untuk pengaruh tidak langsung melalui pemanfaatan sumber belajar $\left(\mathrm{X}_{2}\right)$ bernilai positif sebesar $5,58 \%$, dan pengaruh total sebesar $10,16 \%$, hal ini menunjukan bahwa kompetensi professional guru secara langsung dan tidak langsung berpengaruh positif terhadap hasil belajar siswa, dimana pengaruh tidak langsung melalui pemanfaatan sumber belajar memiliki nilai yang besar dibandingkan nilai pengaruh langsung. Hal ini menjelaskan bahwasanya semakin baik kompetensi professional guru serta di dukung dengan semakin baiknya siswa dalam memanfaatkan sumber belajar yang ada, maka hal ini akan semakin meningkatkan hasil belajar siswa di sekolah.

Hasil penelitian ini sejalan dengan penelitian Arfah, M dan Muhidin, A (2018:48) tentang Hubungan Kompetensi Profesional Guru Dengan Hasil Belajar Siswa SMK Bidang Keahlian Bisnis dan Manajemen di Kota Bandung menjelaskan bahwa terdapat hubungan antara kompetensi profesional guru dengan hasil belajar siswa. Artinya semakin baik kompetensi professional guru maka akan memberikan hasi belajar yang baik pula bagi peserta didik. Selain itu beberapa kajian terdahulu juga mengemukan jika kompetensi professional guru berpengaruh terhadap hasil belajar, diantaranya yaitu penelitian yang dilakukan oleh Nafis, H., Rusdinal., Ananda, A., Khairani., \& Satria, H (2019), Mutmainnah 
(2018:17), dan Sunarti, I dan Susanti yang mengemukakan jika kompetensi professional guru memiliki pengaruh yang positif dan signifikan terhadap hasil belajar.

\section{5) Pengaruh Pemanfaatan Sumber Belajar Terhadap Hasil Belajar}

Tujuan kelima dalam penelitian ini yakni ingin mengetahui pengaruh pemanfaatan sumber belajar terhadap hasil belajar, pengujian dilakukan melalui Uji-t (Uji Parsial). Dari hasil pengujian pada Tabel 1 yang dilakukan diperoleh angka nilai $t$ hitung variabel $\mathrm{X}_{2}$ sebesar 5,035, dikarenakan nilai t hitung > t Tabel $(5,035>1,975)$, maka secara parsial pemanfaatan sumber belajar memiliki pengaruh terhadap hasil belajar. Oleh karena itu maka $\mathrm{H}_{0}$ ditolak, artinya secara parsial terdapat pengaruh signifikan antara pemanfaatan sumber belajar dengan hasil belajar siswa.

Besarnya pengaruh langsung pemanfaatan sumber belajar $\left(\mathrm{X}_{2}\right)$ terhadap hasil belajar (Y) bernilai positif sebesar 5,58\%, begitu pula untuk pengaruh tidak langsung melalui kompetensi professional guru bernilai positif sebesar 5,58\%, dan pengaruh total sebesar $21,27 \%$, hal ini menunjukan bahwa pemanfaatan sumber belajar secara langsung dan tidak langsung berpengaruh positif terhadap hasil belajar siswa, dimana pengaruh langsung memiliki nilai yang besar dibandingkan nilai pengaruh tidak langsung. Hal ini menjelaskan bahwasanya apabila siswa mampu memanfaatkan sumber belajar yang ada dengan baik, maka hal ini akan mampu meningkatkan hasil belajar siswa disekolah.

Hasil penelitian ini sejalan dengan penelitian yang dilakukan oleh Maharani., Asriati, N., dan Rosyid, R (2014:12), Utami, R.D., Kohar, F., dan Nasori, A (2017:5), dan Savitri, W.A., Sudirman, A., Rapani (2018:1) yang mengemukan bahwa sumber belajar secara positif dan signifikan berpengaruh terhadap hasil belajar.

\section{6) Pengaruh Motivasi Belajar Terhadap Hasil Belajar}

Tujuan keenam dalam penelitian ini yakni ingin mengetahui pengaruh motivasi belajar terhadap hasil belajar, pengujian dilakukan melalui Uji-t (Uji Parsial). Dari hasil pengujian pada Tabel 4.17 yang dilakukan diperoleh angka nilai t hitung variabel $\mathrm{X}_{3}$ sebesar 3,982, dikarenakan nilai t hitung > t Tabel $(3,982>1,975)$, maka secara parsial motivasi belajar memiliki pengaruh terhadap hasil belajar. Oleh karena itu maka $\mathrm{H}_{0}$ ditolak, artinya secara parsial terdapat pengaruh signifikan antara motivasi belajar dengan hasil belajar siswa. Dimana besarnya pengaruh motivasi belajar $\left(\mathrm{X}_{3}\right)$ terhadap hasil belajar (Y) bernilai positif sebesar 9,36\%. Hal ini menjelaskan bahwasanya apabila siswa memiliki motivasi belajar yang tinggi, maka hal ini akan semakin meningkatkan hasil belajar siswa disekolah.

Hasil penelitian ini sejalan dengan penelitian yang dilakukan oleh oleh Lin, M.H., Chen, H.C., \& Liu K.S (2017), Rusmono, R., Sulardi, S., \& Suyitno, S (2018), Savitri, W.A., Sudirman, A., Rapani (2018:1), dan Sunarti, I dan Susanti (2016:32) dimana hasil penelitiannya menunjukan bahwa motivasi belajar berpengaruh secara positif dan signifikan terhadap hasil belajar.

\section{7) Pengaruh Kompetensi Profesional Guru dan Pemanfaatan Sumber Belajar Melalui Motivasi Belajar Terhadap Hasil Belajar.}

Dari proses perhitungan analisis jalur yang dilakukan dapat disimpulkan bahwa kompetensi professional guru terhadap hasil belajar melalui motivasi belajar pengaruhnya sebesar $1,38 \%$, dan pegaruh kompetensi professional guru terhadap hasil belajar melalui pemanfaatan sumber belajar dan motivasi belajar sebesar 2,80\% dan total pengaruhnya adalah sebesar 4,18\% dimana angka tersebut menjelaskan bahwa kompetensi professional guru melalui motivasi belajar memberikan sumbangan terhadap hasil belajar siswa pada SMA Negeri 1 Bayung Lencir.

Sedangkan pemanfaatan sumber belajar terhadap hasil belajar melalui motivasi belajar pengaruhnya sebesar $7,88 \%$, dan pegaruh pemanfaatan sumber belajar terhadap hasil belajar melalui kompetensi professional guru dan motivasi belajar sebesar 1,68\% dan total pengaruhnya adalah sebesar $9,56 \%$ dimana angka tersebut menjelaskan bahwa pemanfaatan 
sumber belajar melalui motivasi belajar memberikan sumbangan terhadap hasil belajar siswa pada SMA Negeri 1 Bayung Lencir.

Kemudian pengaruh langsung kompetensi professional guru dan pemanfaatan sumber belajar secara bersama-sama melalui motivasi belajar terhadap hasil belajar siswa adalah sebesar 9,26\%, pengaruh tidak langsungnya adalah sebesar $4,48 \%$ dan total pengaruhnya adalah sebesar $13,74 \%$. Dengan demikian, secara bersama-sama variabel kompetensi professional guru dan pemanfaatan sumber belajar melalui motivasi belajar memberikan sumbangan terhadap hasil belajar siswa pada SMA Negeri 1 Bayung Lencir.

Memperhatikan hasil perhitungan analisis diatas, dapat disampaikan bahwa kompetensi professional guru dan pemanfaatan sumber belajar melalui motivasi belajar dapat memberikan pengaruh yang signifikan pada hasil belajar siswa, itu artinya terbukti bahwa keberadaan motivasi kerja sangat vital.

Hasil penelitian ini sejalan dengan penelitian yang dilakukan oleh Sunarti, I dan Susanti (2016) yang mengemukakan bahwa kompetensi professional guru melalui motivasi belajar siswa dapat memberikan pengaruh terhadap hasil belajar siswa pada kelas XI IPS SMA Kadugede Kuningan. Selain itu Savitri, W.A., Sudirman, A., Rapani (2018) juga mengemukakan bahwa pemanfaatan sumber belajar berpengaruh terhadap hasil belajar siswa melalui motivasi belajar siswa.

Motivasi laksana jantung bagi terlaksananya dan tercapainya hasil belajar yang memuaskan, sebaliknya belajar tanpa adanya motivasi akan hampa, artinya eksistensi motivasi merupakan sub komponen yang vital dalam pembelajaran, ia sangat memberikan kontribusi bagi keberhasilan belajar. Motivasi menurut Purwanto (2017:60) Dalam proses belajar mengajar, motivasi memilikin peranan yang sangat penting, motivasi adalah syarat mutlak untuk belajar. Dalam proses elajar mengajar, faktor motivasi memiliki peranan yang sangan penting untuk mencapai keberhasilan belajar. Sardiman dalam Khadijah (2014:156) menyatakan bahwa motivasi merupakan keseluruhan daya penggerak dalam diri invidu yang menimbulkan kegiatan belajar, yang menjamin kelangsungan kegiatan belajar, dan yang memberikan arah belajar sehingga tujuan yang dikehendaki akan tercapai.

\section{KESIMPULAN DAN SARAN}

\section{Kesimpulan}

Berdasarkan hasil penelitian dan pembahasan dalam tesis ini, maka dapat disimpulkan sebagai berikut: 1) Kompetensi professional guru berpengaruh positif dan signifikan terhadap motivasi belajar siswa pada SMA Negeri 1 Bayung Lencir; 2) Pemanfaatan sumber belajar berpengaruh positif dan signifikan terhadap motivasi belajar siswa pada SMA Negeri 1 Bayung Lencir; 3) Kompetensi professional guru dan pemanfaatan sumber belajar secara simultan berpengaruh positif dan signifikan terhadap motivasi belajar siswa pada SMA Negeri 1 Bayung Lencir; 4) Kompetensi professional guru berpengaruh positif dan signifikan terhadap hasil belajar siswa pada SMA Negeri 1 Bayung Lencir; 5) Pemanfaatan sumber belajar berpengaruh positif dan signifikan terhadap hasil belajar siswa pada SMA Negeri 1 Bayung Lencir; 6) Motivasi belajar berpengaruh positif dan signifikan terhadap hasil belajar siswa pada SMA Negeri 1 Bayung Lencir; dan 7) Kompetensi professional guru dan pemanfaatan sumber belajar secara bersama-sama melalui motivasi belajar dapat berpengaruh langsung dan tidak langsung terhadap terhadap hasil belajar siswa pada SMA Negeri 1 Bayung Lencir.

\section{Saran-saran}

Adapun saran yang dapat diberikan melalui hasil penelitian yang telah dilakukan adalah sebagai berikut: 


\section{Secara Praktis}

a. Guru diharapkan dapat meningkatkan kompetensi profesionalnya, dengan cara mengupgrade diri dalam segi ilmu dan teknologi, dengan training berkala untuk meningkatkan kemampuan teknologi para guru, membangun Forum Group Discussion (FGD) antar sesama guru, serta mengikuti kursus ataupun pelatihan menggunakan media kreatif untuk mengembangkan media pembelajaran.

b. Siswa diharapkan lebih meningkatkan motivasi belajar, serta dapat memanfaatkan sumber belajar yang telah tersedia disekolah maupun di luar lingkungan sekolah untuk menambah wawasan dan pengetahuan yang sejalan dengan perkembangan IPTEK.

c. Pimpinan sekolah diharapkan dapat meningkatkan kualitas fasilitas dan memperhatikan kelengkapan dan kondisi yang memadai untuk menunjang kegiatan belajar mengajar. Selain itu kepala sekolah juga diharapkan dapat terus meningkatkan kompetensi guru, khususnya kompetensi professional melalui program pelatihan dan pendidikan.

\section{SecaraAkademis}

Penelitian ini perlu ditindak lanjuti lagi untuk melihat faktor apa yang dapat memengaruhi hasil belajar siswa secara komprehensif, guna menjawab faktor lain (epsilon) yang mempengaruhi hasil belajar siswa. Faktor-faktor tersebut dapat berupa bersumber dari luar maupun dalam diri individu siswa tersebut. Dari luar dapat berupa lingkungan sekolah, lingkungan social, maupun instrument lainnya berupa guru, sarana dan fasilitas. Sedangkan yang bersumber dari dalam dapat berupa bakat, minat, kecerdasan, serta kemampuan kognitif.

\section{DAFTAR RUJUKAN}

Anni, C.T. 2014. Psikologi Belajar. Semarang: Unnes Press.

Arfah, M dan Muhidin, A. 2018. Hubungan Kompetensi Profesional Guru Dengan Hasil Belajar Siswa SMK Bidang Keahlian Bisnis dan Manajemen di Kota Bandung. Jurnal Pendidikan Manajemen Perkantoran, Vol. 3, No. 2.

Dimyati dan Mudjiono. 2009. Belajar dan Pembelajaran. Jakarta: Rineka Cipta.

Khadijah, N. 2014. Psikologi Pendidikan. Jakarta: Rajawali Pers.

Khairinal. 2016. Menyusun: Proposal, Skripsi, Tesis \& Disertasi. Jambi: Salim Media Indonesia.

Lin, M.H., Chen, H.C., \& Liu K.S. 2017. A Study of the Effects of Digital Learning on Learning Motivation and Learning Outcome. EURASIA Journal of Mathematics Science and Technology Education, 13 (7).

Luthan, F. 2006. Perilaku Organisasi. Yogyakarta: Andi

Maharani., Asriati, N., dan Rosyid, R. 2014. Pengaruh Pemanfaatan Sumber Belajar Terhadap Hasil Belajar Akuntansi di SMK N 3 Pontianak. Artikel Universitas Tanjungpura Pontianak.

Mulyasa, E. 2013. Standar Kompetensi dan Sertifikasi Guru. Bandung: PT. Remaja Rosdakarya.

Mutmainnah. 2018. Pengaruh Kompetensi Profesional Terhadap Hasil Belajar Peserta Didik Kelas IV pada Mata Pelajaran Matematika di Sekolah Dasar Islam AL-Azhar 21 Pontianak Tahun 2017-2018. Jurnal Pengembangan Pendidikan Dasar, Volume 1, Nomor 1.

Nafis, H., Rusdinal., Ananda, A., Khairani., \& Satria, H. 2019. Influence Of Professional Teacher Competence, Self Concept, Interest Learning, And Early To Learning Outcomes Mathemathics. International Journal of Innovative Technology and Exploring Engineering (IJITEE) ISSN: 2278-3075, Volume-8 Issue-10.

Purwanto, M. Ngalim. 2017. Psikologi Pendidikan. Bandung: PT. Remaja Rosdakarya. 
Robbins, S.P dan Judge, T.A. 2015. Perilaku Organisasi. Jakarta: Salemba Empat.

Rusmono, R., Sulardi, S., \& Suyitno, S. 2018. Influence of learning model and learning motivation to learning outcome of micro hydro power plant. 3rd Annual Applied Science and Engineering Conference.

Sagala, S. 2011. Kemampuan Profesional Guru dan Tenaga Kependidikan. Bandung: Alfabeta.

Sardiman. 2012. Interaksi dan Motivasi Belajar Mengajar. Jakarta: RajaGrafindo Persada.

Savitri, W.A., Sudirman, A., Rapani. 2018. Hubungan Pemanfaatan Sumber Belajar Dan Motivasi Belajar Dengan Hasil Belajar Matematika Siswa. Jurnal Pedagogi, Vol. 7, No. 4.

Schunk, D.H. 2012. Learning Theories: An Educational Perspective. Teori-Teori Pembelajaran: Perspektif Pendidikan. Yogyakarta: Pustaka Pelajar.

Schunk, D.H., Pintrich, P.P., \& Meece, J.L. 2012. Motivasi Dalam Pendidikan: Teori, Penelitian, dan Aplikasi. Jakarta: PT. Indeks.

Shadrina, D.N., Asriati, N., dan Utomo, B.B. 2015. Pengaruh Kompetensi Profesional Guru Terhadap Hasil Belajar Siswa Mata Pelajaran Ekonomi Kelas X di SMA/MA Negeri Pontianak.

Slameto. 2015. Belajar dan Faktor-Faktor yang Mempengaruhinya. Jakarta: Rineka Cipta.

Sudjana, N. 2016. Penilaian Hasil Proses Belajar Mengajar. Bandung: PT. Remaja Rosda Karya.

Sudjana, N dan Rivai, A. 2009. Teknologi Pengajaran. Bandung : Sinar Baru.

Sugiyono. 2012. Metode Penelitian Pendidikan. Bandung: Alfabeta.

Sunarti, I dan Susanti. 2016. Pengaruh Kompetensi Profesional Guru Terhadap Motivasi Belajar Siswa Serta Implikasinya Terhadap Hasil Belajar Siswa (Survey Terhadap Hasil Belajar Siswa Kelas XI IPS SMA Kadugede Kuningan. Jurnal Equilibrium, Vol. 14.

Supardi. 2015. Penilaian Autentik: Pembelajaran Afektif, Kognitif, dan Psikomotor (Konsep dan Aplikasi). Jakarta: Rawali Pers.

Syah, M. 2017. Psikologi Pendidikan Dengan Pendekatan Baru. Bandung: PT. Remaja Rosdakarya Offset.

Uno, Hamzah, B. 2017. Teori Motivasi \& Pengukurannya. Jakarta: PT. Bumi Aksara.

Utami, R.D., Kohar, F., dan Nasori, A. 2017. Pengaruh Manajemen Diri Dan Pemanfaatan Sumber Belajar Terhadap Hasil Belajar Siswa Pada Mata Pelajaran Ekonomi Kelas XI IPS Sman 11 Kota Jambi. Artikel Ilmiah.

Warsita, B. 2010. Pendidikan Jarak Jauh. Bandung. PT Remaja Rosdakarya.

Wati, N.D.K., Nuraini., Bambang, GS. 2016. Hubungan Pemanfaatan Sumber Belajar Dengan Motivasi Belajar Mata pelajaran Ekonomi Siswa Kelas XI SMA. 